\title{
Timescales and Magnitude of Water Quality Change in Three Texas Estuaries Induced by Passage of Hurricane Harvey
}

\author{
Lily M. Walker ${ }^{1} \cdot$ Paul A. Montagna ${ }^{1} \cdot$ Xinping Hu${ }^{2} \cdot$ Michael S. Wetz ${ }^{1}$
}

Received: 3 April 2020 / Revised: 23 September 2020 / Accepted: 2 October 2020 / Published online: 14 October 2020

(C) The Author(s) 2020

\begin{abstract}
Tropical cyclones represent a substantial disturbance to water quality in coastal ecosystems via storm surge, winds, and flooding. However, evidence to date suggests that the impacts of tropical cyclones on water quality are generally short-lived (days-months) and that the magnitude of the disturbance is related to proximity to storm track. Discrete and continuous water samples were collected in three Texas estuaries before and after Hurricane Harvey made landfall in 2017. Of the three estuaries, the Guadalupe Estuary and its watershed received the highest rainfall totals and wind speeds. An ephemeral increase in salinity was observed (mean of 9.8 on 24 August 2017 to a peak of 32.1 on 26 August 2017) due to storm surge and was followed by a rapid decrease to $<1$ as floodwaters reached the estuary. Salinity returned to pre-storm levels within 1 month. During the low salinity period, bottom water hypoxia developed and lasted for 9 days. In all three estuaries, there was an increase in inorganic nutrients postHarvey, but the nutrients largely returned to pre-storm baseline levels by winter. The lack of long-term water quality impacts from Harvey despite its severity corroborates previous findings that estuarine water quality tends to return to baseline conditions within days to a few months after storm passage.
\end{abstract}

Keywords Hurricane Harvey $\cdot$ Biogeochemistry $\cdot$ Water quality $\cdot$ Texas $\cdot$ Estuaries $\cdot$ Flood

\section{Introduction}

Tropical cyclones can lead to dramatic short-term changes in estuarine water quality (Wetz and Yoskowitz 2013). For example, tropical cyclone-driven flooding can rapidly reduce salinity and lead to strong stratification. In addition, it can deliver copious amounts of allochthonous organic matter and nutrients to the estuary (Paerl et al. 1998). Respiration of the allochthonous organic matter as well as organic matter from any phytoplankton blooms that develop can cause bottom water hypoxia-anoxia (Paerl et al. 1998, 2001; Mallin

Communicated by Arnoldo Valle-Levinson

Electronic supplementary material The online version of this article (https://doi.org/10.1007/s12237-020-00846-6) contains supplementary material, which is available to authorized users.

Lily M. Walker

lwalker2@islander.tamucc.edu

1 Harte Research Institute for Gulf of Mexico Studies, Texas A\&M University - Corpus Christi, Corpus Christi, TX, USA

2 Department of Physical and Environmental Sciences, Texas A\&M University - Corpus Christi, Corpus Christi, TX, USA et al. 1999; Peierls et al. 2003; Tomasko et al. 2006). Despite the potential severe impact of tropical cyclones, most studies have shown that estuarine water quality conditions typically return to pre-storm conditions in 1 month or less (Valiela et al. 1998; Hagy et al. 2006; Tomasko et al. 2006), although longer-term effects have been observed with less frequency (Glibert et al. 2009; Briceño and Boyer 2010).

Long-term effects of tropical cyclones on estuarine water quality have rarely been documented, due in part to lack of continuous time series that would otherwise allow for impacts to be placed in the context of a historical, longer-term timeframe. However, some studies using continuous time series have captured long-term effects of tropical cyclones. One example comes from North Carolina's Neuse River EstuaryPamlico Sound, where a multidecadal water quality time series exists. Following the passage of three hurricanes in 1999, recovery times for key water quality variables ranged from 1 to 2 months for dissolved nutrients to $\sim 8$ months for salinity and chlorophyll (Peierls et al. 2003). Using long-term National Estuarine Research Reserve data from Apalachicola Bay, FL, Geyer et al. (2018) quantified the effects of a series of four tropical cyclones that struck in 2004 and three more in 2005. Those authors found a period of persistently low chlorophyll throughout 2005, presumably due to high flushing 
rates and low light availability. In Florida Bay, a series of three hurricanes in 2005 were followed by a 3 -year picocyanobacteria bloom (Glibert et al. 2009). The long residence times in some regions of Florida Bay may have allowed for the retention and recycling of storm-driven allochthonous nutrients that fueled this bloom (Glibert et al. 2009; Briceño and Boyer 2010; Lee et al. 2016).

Here, we have quantified the short-term (days to weeks) and long-term (up to 9 months post-storm) effects of Hurricane Harvey on select water quality indicators in three Texas estuaries: Guadalupe (GE), Lavaca-Colorado (LC), and Nueces-Corpus (NC). These systems are shallow $(<5 \mathrm{~m})$, well mixed by winds, have minimal tidal influence $(\sim 15 \mathrm{~cm}$, Zetler and Hansen 1970), and are separated from the Gulf of Mexico by a series of barrier islands. Despite similar geomorphology, hydrology varies between the three systems and influences biogeochemical processes (Montagna et al. 2018). There is a natural precipitation gradient along the Texas coast, with decreasing precipitation and increasing salinity from the northeast to southwest (Montagna et al. 2013). As a result of this precipitation gradient, LC and GE are considered positive estuaries because freshwater inputs exceed evaporation on average, while $\mathrm{NC}$ is considered a neutral estuary where freshwater inputs are roughly balanced by evaporation (Montagna et al. 2018). Hurricane Harvey made landfall near Port Aransas, TX, on 26 August 2017, accompanied by category 4 winds and heavy rainfall totaling over $152 \mathrm{~cm}$ in areas. After slowly moving inland, the storm looped back seaward and exited the coast over LC on 28 August before slowly moving to the northeast away from Texas. This study provides critical data on the timescales of water quality impacts from this very high intensity tropical cyclone. This is important given recent projections suggesting that anthropogenic climate change may lead to an overall decrease in the frequency of tropical cyclones but an increase in the wind or rainfall intensity (Christensen et al. 2013; Knutson et al. 2015; Emanuel 2017; Patricola and Wehner 2018).

\section{Methods}

\section{Data Sources}

Discrete water quality data were obtained from eight sampling sites in GE, nine in LC, and nine in NC (Fig. 1). Sampling sites were designed to capture estuarine salinity gradients. In addition, high-frequency continuous water quality data was collected from one site in GE (Fig. 1). Of the three estuaries, GE was closest in proximity to Harvey's landfall and experienced the most severe weather impacts (a combination of surge, wind, and rain) (Fig. 1). River discharge data were obtained from the National Oceanic and Atmospheric Administration's (NOAA) National Climatic Data Center and the United States Geological Survey. Inflow to LC was calculated as the summed inflow from the Lavaca (USGS gauge 08164000) and Tres Palacios Rivers (USGS gauge 08162600). Wind data (recorded at $0.8 \mathrm{~m}$ above mean sea level) was obtained from NOAA Tides and Currents Seadrift, TX station (\# 8773037).

\section{Discrete Sample Collection}

Discrete water samples were collected at varying frequencies, with low-frequency collections (typically quarterly) occurring prior to Harvey, and more frequent collections (biweekly to monthly) occurring after Harvey. Surface ( $\sim 0.1 \mathrm{~m}$ depth) water was collected for chlorophyll $a(\mathrm{Chl} a)$ and inorganic nutrients in acid-washed, amber high-density polyethylene bottles and immediately stored on ice for transport to the lab. A hydrographic depth profile (every $0.5 \mathrm{~m}$ ) of dissolved oxygen, $\mathrm{pH}$, salinity, temperature, and conductivity was recorded using a YSI multiparameter sonde at all stations and time points. Sondes underwent pre- and post-calibration of these variables using certified laboratory-grade standards to ensure quality control of the data.

\section{Nutrient and $\mathrm{Chl} a$ Analysis}

Samples from two different sampling programs under different investigators were utilized to broaden the data set. For all LC samples, NC samples collected prior to 2018, and GE samples collected prior to 2017, Chl $a$ was collected by filtering $(<5 \mathrm{mmHg})$ a known volume $(25-50 \mathrm{~mL})$ of sample water (determined based on turbidity conditions) through Whatman $25 \mathrm{~mm}$ GF/F filters. Filters were then stored frozen before analysis, which took place within 30 days. Samples were filtered in the field and stored on dry ice for transport to the lab. Chl $a$ was extracted overnight using methanol and read fluorometrically on a Turner Model 10-AU using the non-acidification technique. For the remaining $\mathrm{NC}$ and GE Chl $a$ samples, a known volume $(25-50 \mathrm{~mL})$ of sample water was filtered $(<5 \mathrm{mmHg})$ through Whatman $25 \mathrm{~mm} \mathrm{GF} / \mathrm{F}$ filters that were then stored frozen $\left(<-20^{\circ} \mathrm{C}\right)$ for future analysis within 30 days. Chl $a$ was extracted from the filters by soaking in 90\% HPLC-grade acetone for 16-24 h. Fluorometric determination of $\mathrm{Chl} a$ was performed with a Turner Trilogy fluorometer without acidification.

Inorganic nutrient concentrations [(nitrate + nitrite $\left(\mathrm{NO}_{\mathrm{x}}\right)$, ammonium, orthophosphate, silicate] were also determined according to two different methods, depending on the investigator and program. For samples collected prior to May 2017 (GE) or October 2017 (LC, NC), nutrient concentrations were obtained from the filtrate of water that passed through a $0.45-\mu \mathrm{m}$ polycarbonate filter and stored frozen $\left(-20^{\circ} \mathrm{C}\right)$ until analysis. Samples were analyzed with an O.I. Analytical Flow Solution IV analyzer. Check standards of known 
Fig. 1 Map of sampling sites and storm trajectory. Total precipitation data (source: National Oceanographic and Atmospheric Administration) from August 25th to September 4th, 2017, was interpolated using inversed distance weighting and is displayed as a color map. Intervals were chosen based on natural breaks within the data shown in the map's extent. The path and chronologic strength of the hurricane is shown as the multi-colored line. The black dots represent sampling locations. The star indicates the sampling location of site A in GE where continuously recording water quality sondes were deployed preand post-Hurricane Harvey

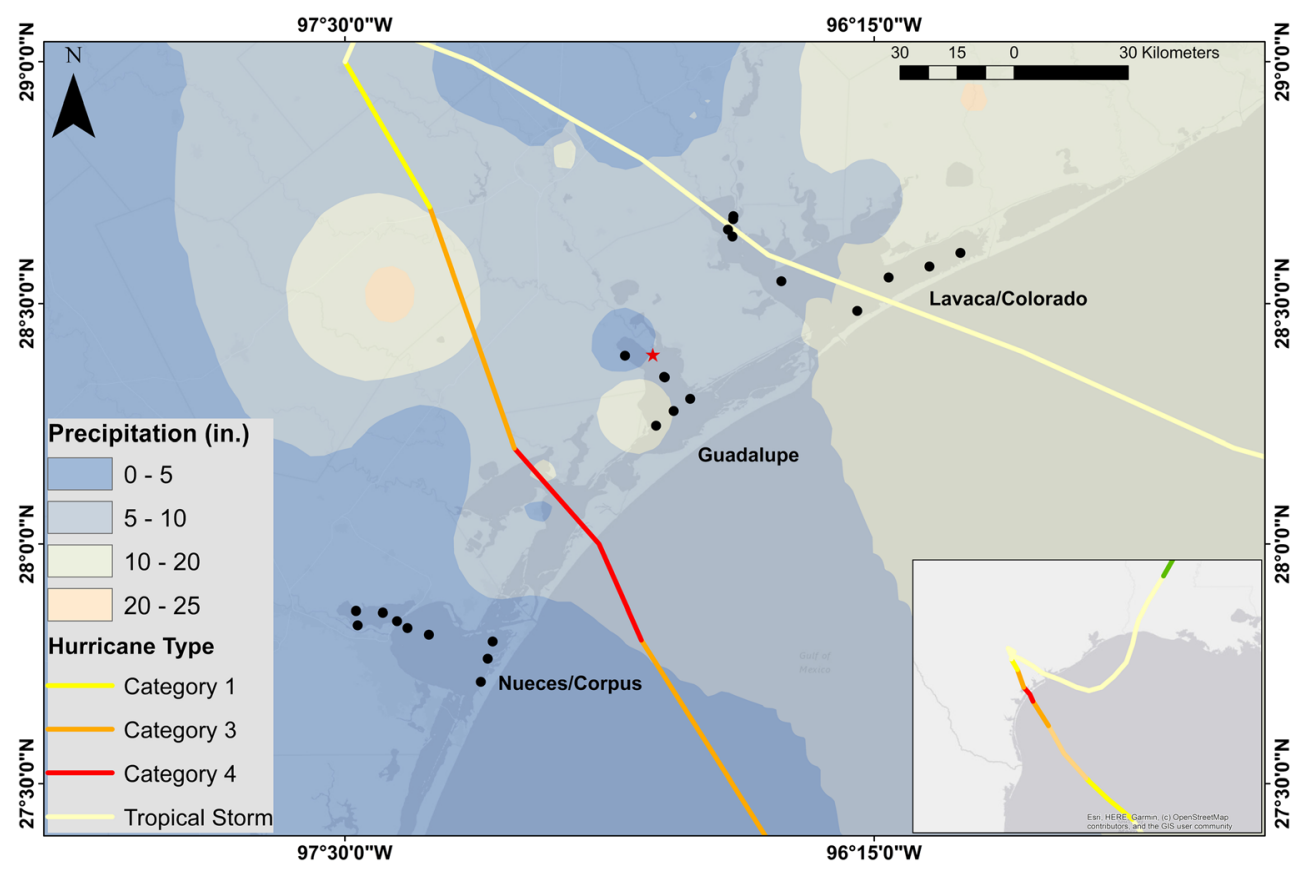

concentrations, as well as matrix spikes and laboratory duplicates, were run after every 10 samples. For samples collected from May 2017 through 2018 (GE) or October 2017 through 2018 (LC, NC), inorganic nutrient concentrations were determined from the filtrate of water samples that were passed through GF/F filters and stored frozen $\left(-20^{\circ} \mathrm{C}\right)$ until analysis. After thawing to room temperature, samples were analyzed on a Seal QuAAtro autoanalyzer. Standard curves with five different concentrations were run daily at the beginning of each run. Fresh standards were made prior to each run by diluting a primary standard with low nutrient surface seawater. Deionized water (DIW) was used as a blank, and DIW blanks were run at the beginning and end of each run, as well as after every 8-10 samples to correct for baseline shifts. Because of the two different filtration procedures used, we ran a series of tests to compare nutrient concentrations in filtrate of estuarine water that passed through $0.45-\mu \mathrm{m}$ polycarbonate filters and $\mathrm{GF} / \mathrm{F}$ filters. The water was collected from a high and a low nutrient site in Oso Bay (TX), and samples were run in triplicate for each filter type and site. Results showed no significant difference in any of the analytes measured (Wetz, unpubl. data, available upon request), consistent with previous work by Knefelkamp et al. (2007), who also found no significant difference in the same nutrient analytes across the same filter pore sizes.

\section{High-Frequency Water Quality Monitoring}

Hydrolab DS5X sondes were deployed on the surface $(0.1 \mathrm{~m}$ below water surface) and bottom ( $0.1 \mathrm{~m}$ above sediment) at the site closest to the river mouth (site A; 1.7 m mean water depth) in GE (Fig. 1). Salinity, pH, dissolved oxygen (D.O.), and temperature were measured at 15-min intervals from May to December of 2017. Datasondes were calibrated prior to deployment and traded out every 5-14 days depending on biofouling and weather conditions. Continuous sonde data underwent rigorous post-deployment quality control to eliminate erroneous data resulting from probe malfunction, biofouling, and drift. Upon retrieval of sondes, probes were checked with known calibration standards before cleaning to assess the accuracy of data recorded in the field. If values were outside an established acceptance range, data for that parameter was omitted. Acceptance ranges were $\pm 0.2{ }^{\circ} \mathrm{C}$ (temperature), \pm $5 \%$ (specific conductance), $\pm 0.5(\mathrm{pH})$, and $\pm 0.5 \mathrm{mg} \mathrm{L}^{-1}$ (D.O.).

\section{Statistical Analyses}

Using R version 3.6.1, ANOVA's were used to test for differences between pre- and post-Harvey water quality conditions by season (one ANOVA per water quality variable per system). A post-hoc Shaffer adjustment was used due to the unbalanced nature of the data. Comparisons were made for preHarvey conditions consisting of January 2013 to August 2017 data and post-Harvey conditions consisting of September 2017 to August 2018 data.

\section{Results}

\section{Rainfall, River Discharge, and Wind}

Mean annual rainfall throughout the study period was 119, 99, and $84 \mathrm{~cm}$ in LC, GE, and $\mathrm{NC}$, respectively (data not shown). 
Seasonal rainfall patterns were apparent, with higher rainfall observed in the spring and fall. Above average rainfall was observed in 2015 and 2018, which is linked to El Niño conditions. Mean daily river discharge throughout the study period (2013-2018) was $13 \pm 74,42 \pm 26$, and $5 \pm 20 \mathrm{~m}^{3} \mathrm{~s}^{-1}$ in LC, GE, and NC, respectively. Discharge increased from $21.0 \mathrm{~m}^{3} \mathrm{~s}^{-1}$ just prior to Harvey (24 August 2017) to a peak of $172.7 \mathrm{~m}^{3} \mathrm{~s}^{-1}$ on 1 September 2017 in GE (Fig. 2). In LC, discharge increased from $0.40 \mathrm{~m}^{3} \mathrm{~s}^{-1}$ on 24 August 2017 to a peak of $2077.0 \mathrm{~m}^{3} \mathrm{~s}^{-1}$ on 29 August 2017 (Fig. 2). A smaller increase was observed for $\mathrm{NC}$, from $0.0 \mathrm{~m}^{3} \mathrm{~s}^{-1}$ on 24 August 2017 to $3.6 \mathrm{~m}^{3} \mathrm{~s}^{-1}$ on 27 August 2017 (Fig. 2). Mean wind speed throughout the study period was $4.1 \mathrm{~m} \mathrm{~s}^{-1}$ at GE and $5.1 \mathrm{~m} \mathrm{~s}^{-1}$ at NC. Mean annual wind speed data was not available for LC. During Harvey, peak wind speed was observed nearest GE on 26 August 2017 at $27.1 \mathrm{~m} \mathrm{~s}^{-1}$ (Fig. S1).

\section{Effects of Hurricane Harvey on Guadalupe Estuary Water Quality on Sub-Daily to Seasonal Timescales}

Bay-wide water temperature was $\sim 31{ }^{\circ} \mathrm{C}$ in the week prior to Harvey (Fig. 3). By early September, just after Harvey's passage, water temperature dropped to $28{ }^{\circ} \mathrm{C}$. After a gradual warm up to $29^{\circ} \mathrm{C}$ by early October, temperature then declined throughout the winter, consistent with historical seasonal patterns in the system (unpubl. data). In the week prior to passage of Harvey, mean salinity was $14.7 \pm 5.9$ and mean bottom water D.O. was $7.1 \pm 0.8 \mathrm{mg} \mathrm{L}^{-1}$ for four sites along the estuary axis (Fig. 3). Bay-wide salinity dropped to $2.2 \pm 2.4$ in the week following Harvey and did not return to pre-storm conditions until October 2017. Salinity stratification (bottom minus surface salinity) was present (14-18 difference among bottom and surface conditions) at mid to lower estuary sites during the week following Harvey (Fig. 4). This stratification was ephemeral, as it dissipated by early September. Bay-wide mean bottom D.O. dropped to $5.0 \pm 3.3 \mathrm{mg} \mathrm{L}^{-1}$ in the week following Harvey and remained below the pre-storm average until mid-September (Fig. 3). D.O. was lowest at site A $\left(0.9 \mathrm{mg} \mathrm{L}^{-1}\right)$ during this timeframe (Fig. 4). Concurrent with the decrease in D.O. was a decrease in pH (Figs. 3, 4). Baywide mean bottom water $\mathrm{pH}$ dropped from $8.1 \pm 0.2$ in the week prior to Harvey to $7.6 \pm 0.2$ in the week following Harvey and returned to pre-storm levels within 2 weeks. Salinity, D.O., and pH increased with increased distance from the river mouth (Fig. 4). Secchi depth decreased after Harvey (minimum depth of $0.15 \pm 0.01 \mathrm{~m}$ in late September 2017), and did not return to pre-storm levels until October 2017 (Fig. $3)$. Following this return, Secchi depths were higher than prestorm depths for the remainder of 2017.

High frequency data at site A showed that in the week prior to passage of Harvey, salinity averaged $9.6 \pm 0.6$ (Fig. 5). As Harvey neared landfall, storm surge from the Gulf of Mexico tripled the salinity, but it dropped to pre-storm levels within 3 days as rainfall and runoff from the storm intensified (Fig.
Fig. 2 Daily mean river discharge $\left(\mathrm{m}^{3} \mathrm{~s}^{-1}\right)$ to the (a) LavacaColorado, (b) Guadalupe, and (c) Nueces-Corpus estuaries from January 2013 to December 2018

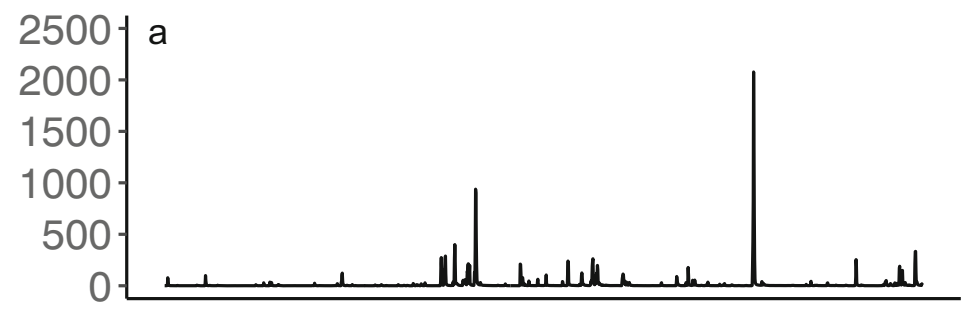

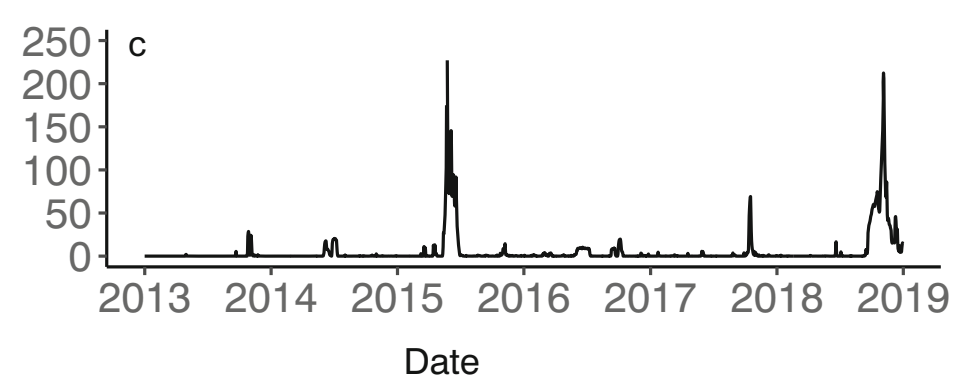


Fig. 3 Bay-wide averages of (a) surface water temperature $\left({ }^{\circ} \mathrm{C}\right)$, (b) surface salinity, (c) bottom dissolved oxygen $\left(\mathrm{mg} \mathrm{L}^{-1}\right),(\mathbf{d})$ bottom $\mathrm{pH}$, and (e) Secchi depth (m) in the Guadalupe Estuary from 22 February to 5 December 2017. Error bars represent standard deviation. The dotted line indicates the date of landfall of Hurricane Harvey

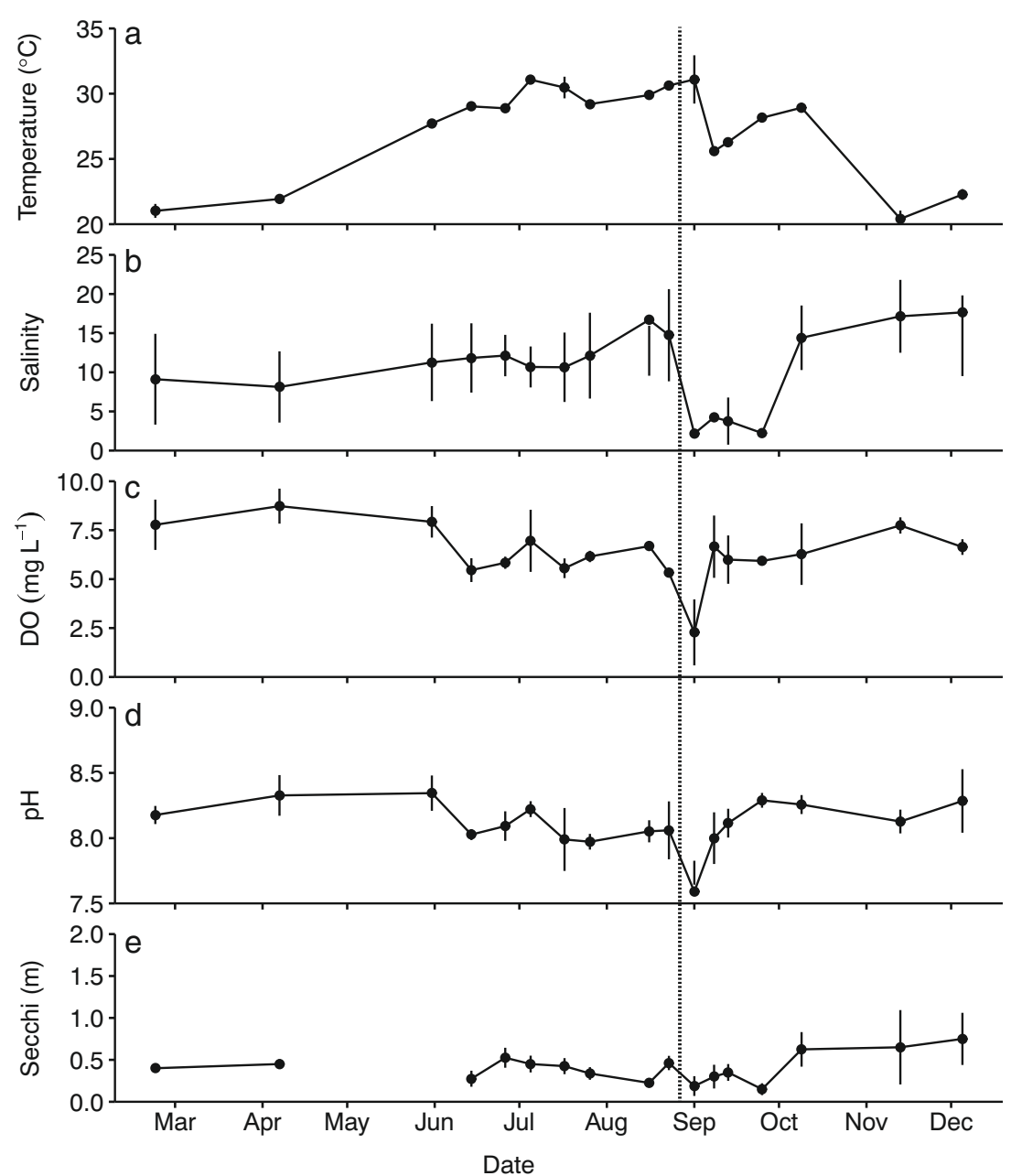

5). By 4 days post-storm (29 August 2017), salinity dropped to $<1$ at site $\mathrm{A}$ and took 37 days to return to pre-storm conditions (Figs. 3, 4). The water column at this site was not stratified during this post-storm period (Fig. 4). Prior to the storm, bottom water D.O. ranged from 3.6 to $8.3 \mathrm{mg} \mathrm{L}^{-1}$ over the daily cycle (Fig. 5). During and immediately following the storm, the daily D.O. cycle was briefly disrupted by high winds and mixing of the water column (Fig. 5). Approximately 5 days after the storm, bottom water hypoxia/anoxia developed and D.O. remained $<2 \mathrm{mg} \mathrm{L}^{-1}$ for 1 week, concurrent with high river inflow (peak mean river discharge of $172.7 \mathrm{~m}^{-3} \mathrm{~s}^{-1}$ on 1 September 2017) and salinity $<1$ (Fig. 5). It took approximately 10 days for bottom D.O. at site A to return to the pre-storm average. Average $\mathrm{pH}$ prior to the storm at site A was 7.94, which dropped to a low of 6.91 during the hypoxic period and took approximately 15 days (14 September 2017) to return to pre-storm levels (Fig. 5).

In July and early August 2017 prior to Harvey, bay-wide $\mathrm{NH}_{4}$ and $\mathrm{PO}_{4}$ averaged $2.4 \pm 4.6$ and $2.4 \pm 0.7 \mu \mathrm{mol} \mathrm{L}{ }^{-1}$, respectively (Fig. 6). $\mathrm{NH}_{4}$ and $\mathrm{PO}_{4}$ increased following the storm to $13.0 \pm 5.8$ and $11.5 \pm 2.7 \mu \mathrm{mol} \mathrm{L}^{-1}$, respectively, by Sep. 8 (Fig. 6). Both variables returned to pre-storm average in
$<1-2$ months. Prior to the storm, $\mathrm{NH}_{4}$ and $\mathrm{PO}_{4}$ peaked at intermediate salinities in the middle/lower estuary, whereas immediately following the storm, highest concentrations were found at the lowest salinities in the upper estuary (Fig. 7). In spring 2018, elevated $\mathrm{NH}_{4}$ was occasionally observed at intermediate salinity conditions (Fig. S2). $\mathrm{NO}_{\mathrm{x}}$ concentrations were only minimally affected by the storm, as a small, ephemeral increase (to $4.6 \pm 2.7 \mu \mathrm{mol} \mathrm{L}{ }^{-1}$ ) was observed in early September (Fig. 6). Prior to Harvey, Chl $a$ was $22.7 \pm$ $9.4 \mu \mathrm{g} \mathrm{L}^{-1}$ at site $\mathrm{A}$ and $20.1 \pm 8.1 \mu \mathrm{g} \mathrm{L}^{-1}$ at all sites in $\mathrm{GE}$ from July to August 2017 (Fig. 6). A slight, but not significant, system-wide decrease in Chl $a$ concentration was observed in early September following the storm (Fig. 6). This was most pronounced in the upper estuary (Fig. 7). Chl $a$ returned to pre-storm averages within 3 weeks following the storm (Fig. 6). There were indications of higher Chl $a$ during both fall and early winter in the upper estuary (Fig. 7).

\section{Comparison of Pre- and Post-Harvey Conditions}

Water quality data from 2013 to 2018 was used to compare effects of Hurricane Harvey with previous water quality 
Fig. 4 Time series of (a) river flow $\left(\mathrm{m}^{3} \mathrm{~s}^{-1}\right)$ and contour plots showing the spatial-temporal distribution of (b) surface salinity, (c) salinity stratification (bottom minus surface salinity), (d) bottom $\mathrm{pH}$, and (e) bottom dissolved oxygen $\left(\mathrm{mg} \mathrm{L}^{-1}\right)$ in the Guadalupe Estuary from 22

February to 31 December 2017
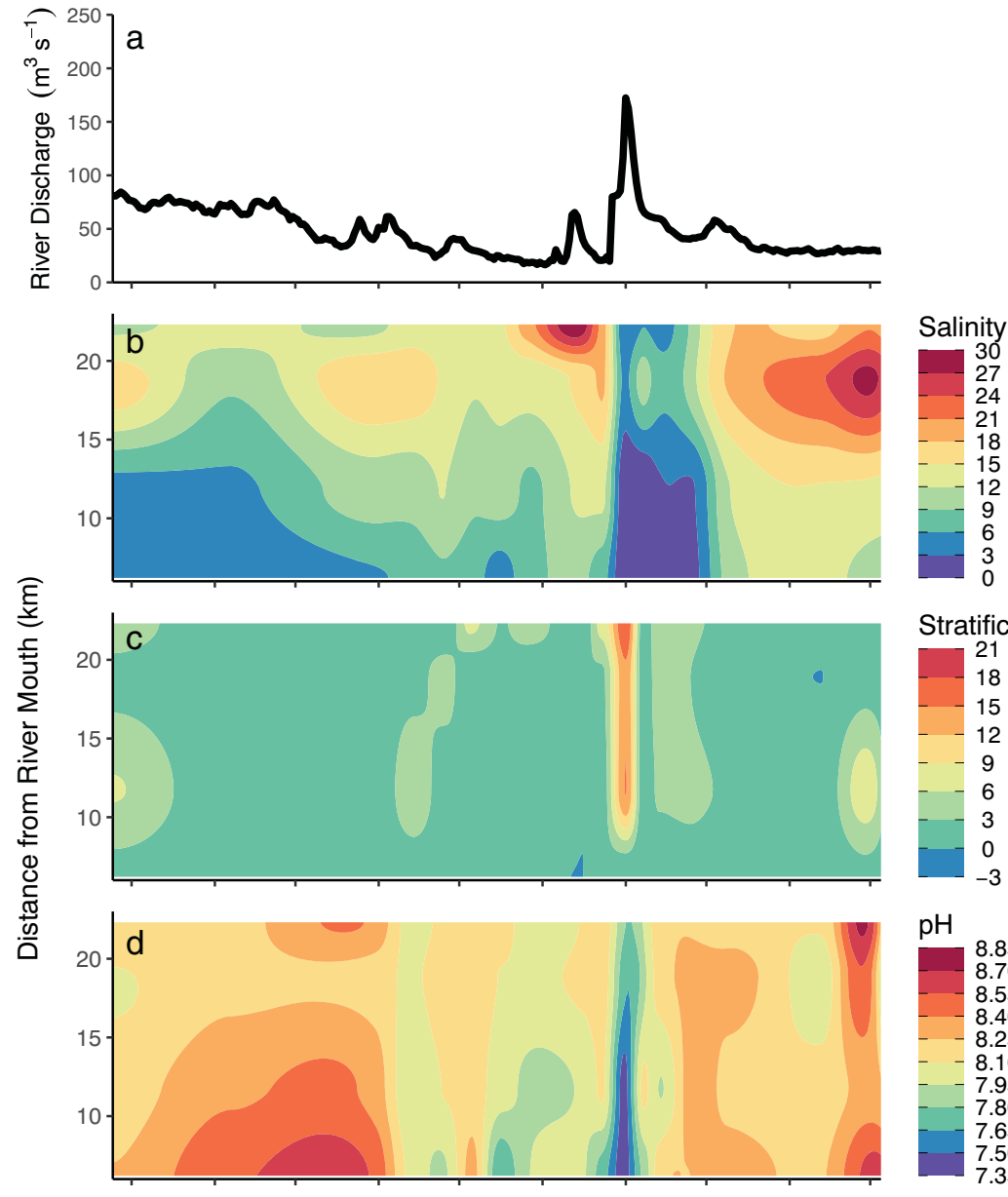

Stratification

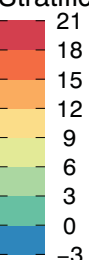

$\mathrm{pH}$
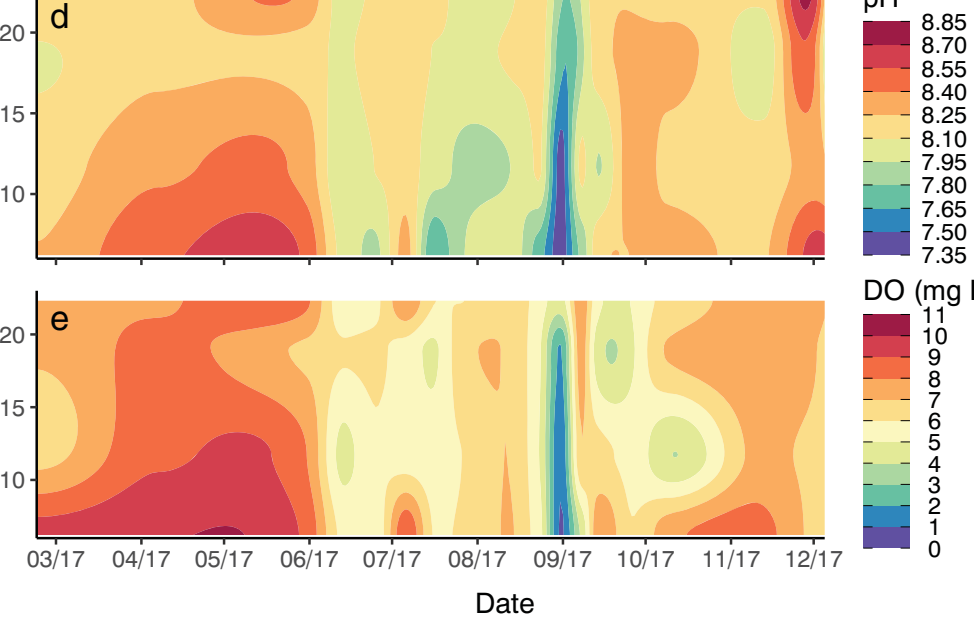

conditions. The most obvious statistically significant effects $(p<0.05)$ of Harvey were noted in comparisons of water quality indicators from the fall post-Harvey vs. fall preHarvey (Table 1). In GE, salinity and $\mathrm{pH}$ were significantly lower post-Harvey $(7.8 \pm 7.1$ vs. $21.7 \pm 8.7$ and $8.0 \pm 0.3$ vs. $8.3 \pm 0.3$, respectively), $\mathrm{PO}_{4}$ concentrations were five times higher post-Harvey $\left(5.2 \pm 3.9\right.$ vs. $\left.1.2 \pm 0.6 \mu \mathrm{mol} \mathrm{L}^{-1}\right), \mathrm{NH}_{4}$ concentrations were four times higher post-Harvey $(4.1 \pm 4.7$ vs. $0.9 \pm 0.9 \mu \mathrm{mol} \mathrm{L}{ }^{-1}$ ), and $\mathrm{NO}_{\mathrm{x}}$ concentrations were three times higher post-Harvey $\left(2.4 \pm 2.8\right.$ vs. $\left.0.8 \pm 0.6 \mu \mathrm{mol} \mathrm{L}^{-1}\right)$. In LC, lower salinities were observed post-Harvey $(16.0 \pm 6.6$ vs. $25.1 \pm 6.1)$, Chl $a$ was higher post-Harvey ( $16.8 \pm 13.3$ vs. $\left.11.1 \pm 5.9 \mu \mathrm{g} \mathrm{L}^{-1}\right), \mathrm{PO}_{4}$ was higher post-Harvey $(2.9 \pm 2.3 \mathrm{vs}$. $\left.1.2 \pm 0.8 \mu \mathrm{mol} \mathrm{L}^{-1}\right)$, and $\mathrm{NH}_{4}$ was higher post-Harvey $(1.0 \pm$ 0.7 vs. $0.8 \pm 1.1 \mu \mathrm{mol} \mathrm{L}^{-1}$ ). In NC, salinity was lower post-
Harvey $(28.1 \pm 3.7$ vs. $34.5 \pm 4.6)$, $\mathrm{pH}$ was lower post-Harvey $(8.1 \pm 0.1$ vs. $8.2 \pm 0.1), \mathrm{NH}_{4}$ was threefold higher postHarvey $\left(1.2 \pm 0.3\right.$ vs. $\left.0.4 \pm 0.4 \mu \mathrm{mol} \mathrm{L}^{-1}\right)$, and $\mathrm{NO}_{\mathrm{x}}$ was lower post-Harvey $\left(0.2 \pm 0.0\right.$ vs. $\left.0.4 \pm 0.3 \mu \mathrm{mol} \mathrm{L}^{-1}\right)$.

Only two water quality indicators displayed a significant difference post-Harvey compared with pre-Harvey during winter. These were $\mathrm{pH}$ in GE, which was 0.2 units higher post-Harvey $(8.4 \pm 0.2$ vs. $8.2 \pm 0.3)$ and $\mathrm{PO}_{4}$ in $\mathrm{NC}$, which was higher post-Harvey $\left(1.1 \pm 0.7\right.$ vs. $\left.0.5 \pm 0.6 \mu \mathrm{mol} \mathrm{L}^{-1}\right)$ (Table 2). Likewise, few significant differences were observed in spring post-Harvey vs. pre-Harvey. Post-Harvey $\mathrm{pH}$ was 0.2 units lower in GE $(8.0 \pm 0.1$ vs. $8.2 \pm 0.2)$ and $<0.1$ units higher in $\mathrm{LC}(8.1 \pm 0.2$ vs. $8.1 \pm 0.2) . \mathrm{NH}_{4}$ was much higher $\left(10.0 \pm 8.3\right.$ vs. $\left.1.8 \pm 2.3 \mu \mathrm{mol} \mathrm{L}{ }^{-1}\right)$ in GE post-Harvey (Table 3). 
Fig. 5 (a) Bottom dissolved oxygen $\left(\mathrm{mg} \mathrm{L}^{-1}\right)$ and salinity and (b) bottom $\mathrm{pH}$ and salinity at site A in the Guadalupe Estuary

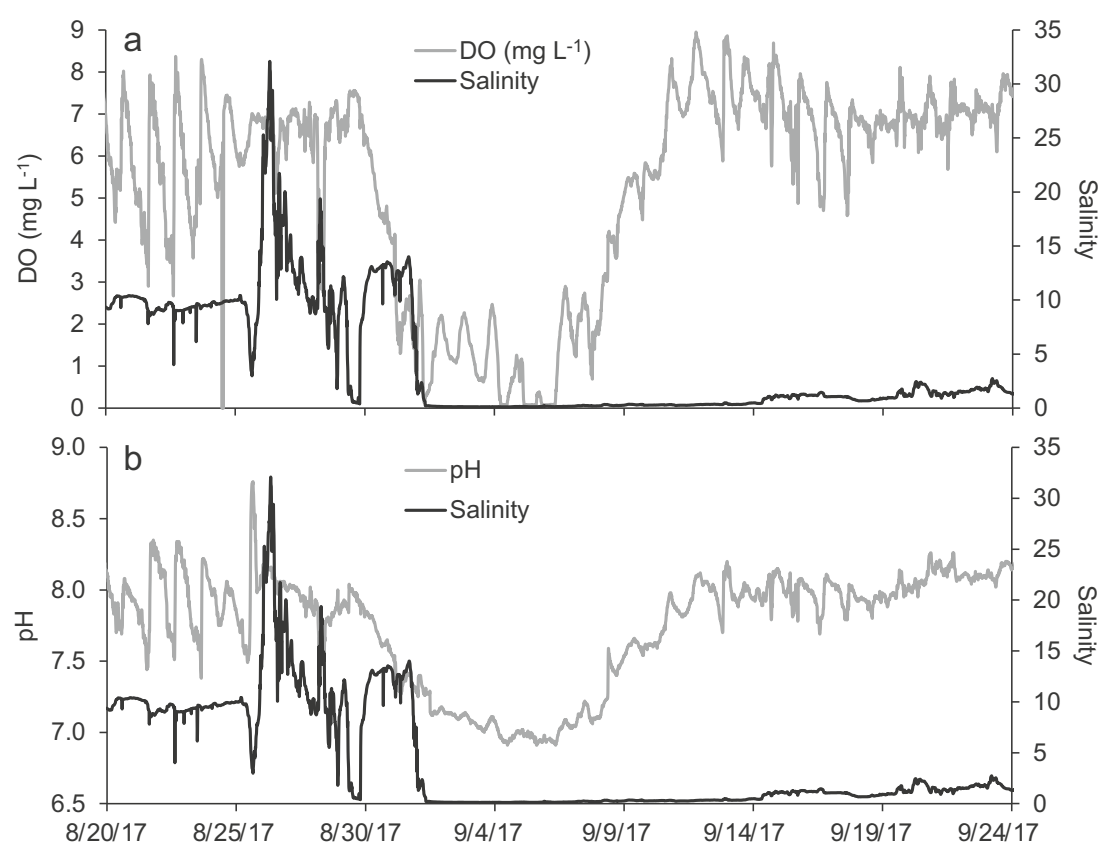

\section{Discussion}

This study analyzed the water quality effects of Hurricane Harvey, a category 4 storm that had high winds and delivered copious rainfall along areas of the Texas coast. Climate projections suggest that tropical cyclone intensity, as well as the frequency of high rainfall events similar to Harvey, may increase in the future due to climate change (Knutson et al.
Fig. 6 Bay-wide averages of (a) surface chlorophyll $a\left(\mu \mathrm{g} \mathrm{L}^{-1}\right)$, (b) surface ammonium $\left(\mathrm{NH}_{4}\right.$ in $\left.\mu \mathrm{mol} \mathrm{L}{ }^{-1}\right),($ c) surface orthophosphate $\left(\mathrm{PO}_{4}\right.$ in $\mu \mathrm{mol}$ $\mathrm{L}^{-1}$ ), and (d) surface nitrate + nitrite $\left(\mathrm{NO}_{\mathrm{x}}\right.$ in $\left.\mu \mathrm{mol} \mathrm{L}{ }^{-1}\right)$ in the Guadalupe Estuary from 22 February to 31 December of 2017. Error bars represent standard deviation. The dotted line indicates the date of landfall of Hurricane Harvey

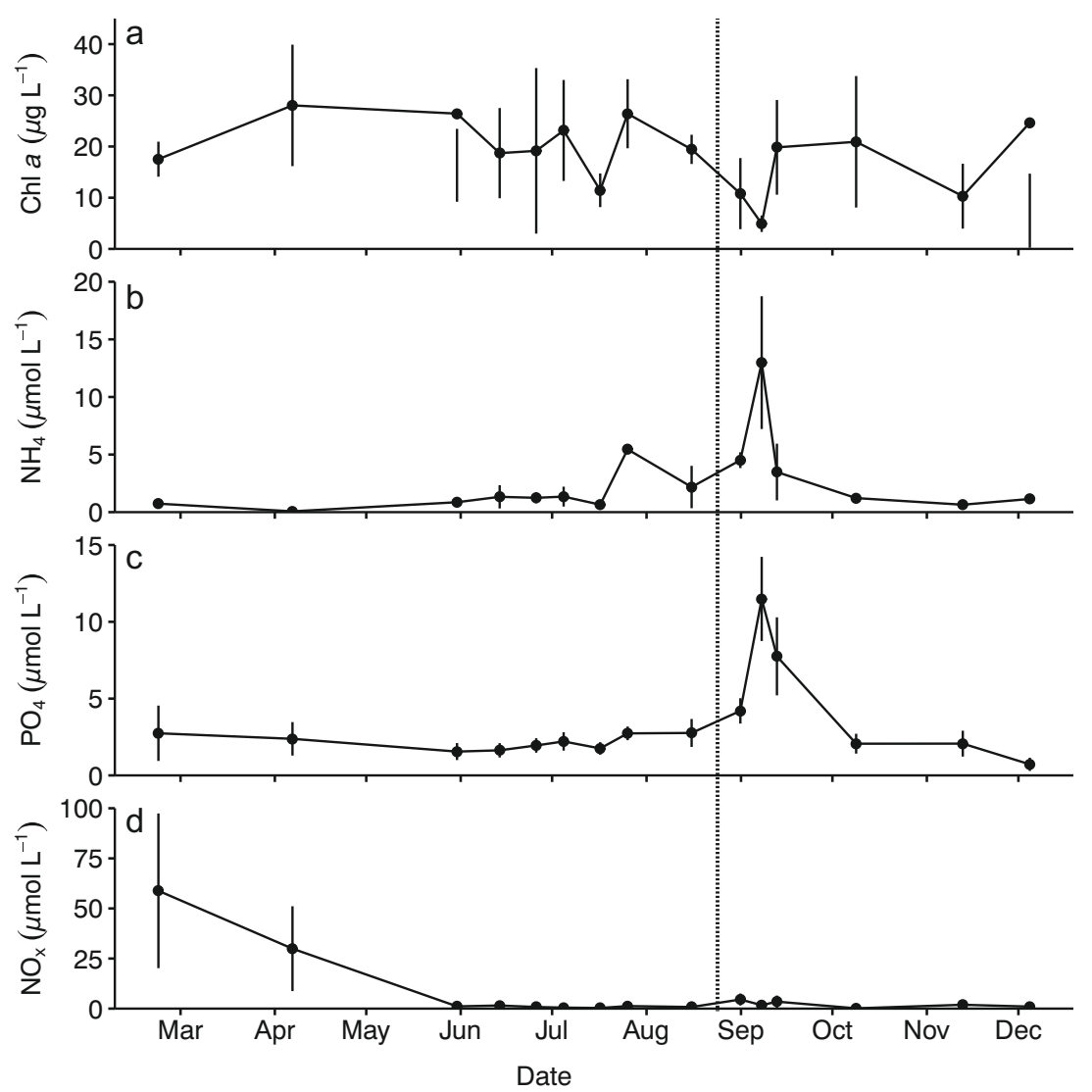


Fig. 7 Time series of (a) river flow $\left(\mathrm{m}^{3} \mathrm{~s}^{-1}\right)$ and contour plots showing the spatial-temporal distribution of (b) surface chlorophyll $a\left(\mu \mathrm{g} \mathrm{L}^{-1}\right),(\mathbf{c})$ surface ammonium $\left(\mathrm{NH}_{4}\right.$ in $\left.\mu \mathrm{mol} \mathrm{L}^{-1}\right)$, and (d) surface orthophosphate $\left(\mathrm{PO}_{4}\right.$ in $\mu \mathrm{mol} \mathrm{L}{ }^{-1}$ ) in the Guadalupe Estuary from 22 February to 31 December 2017
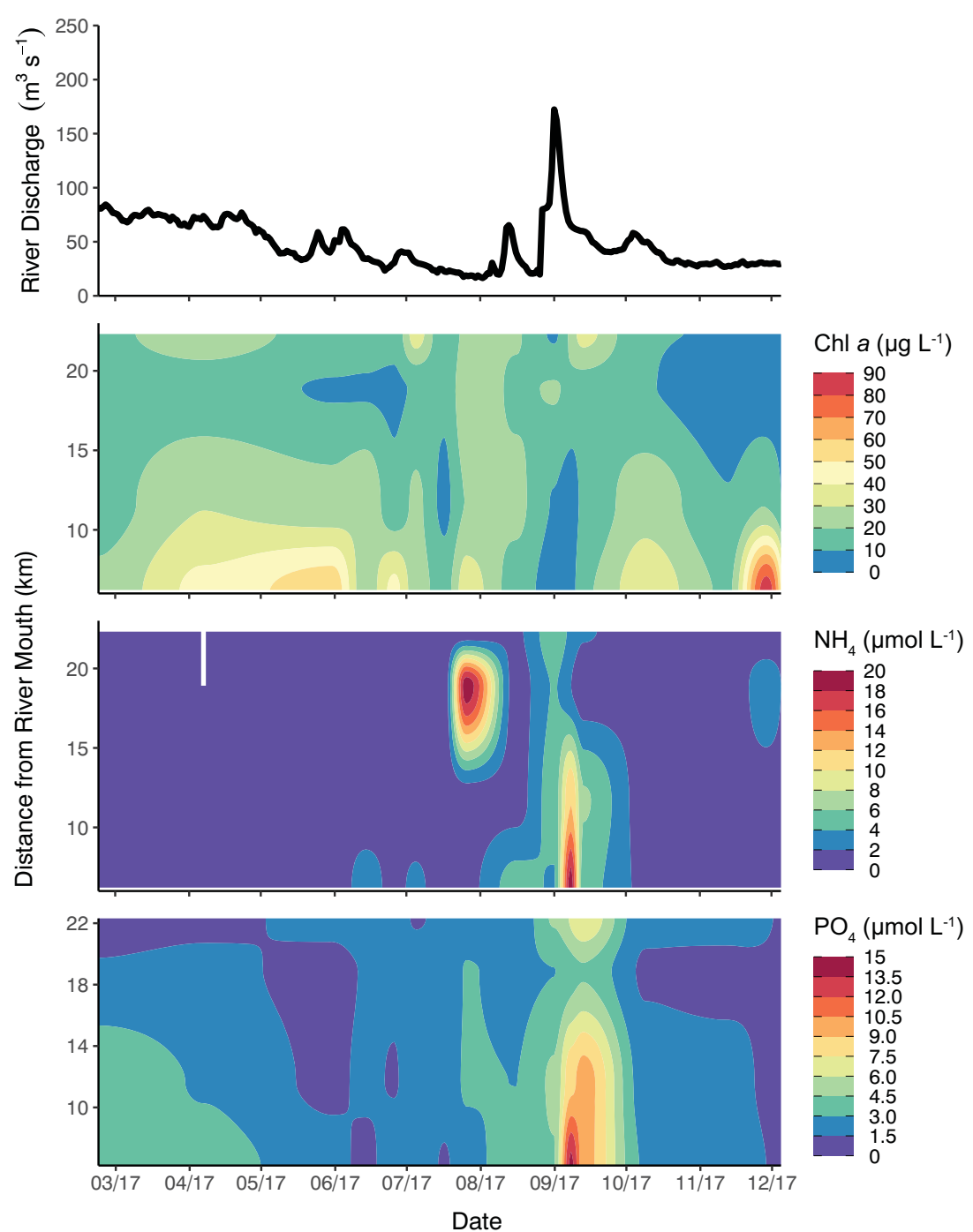

2015; Emanuel 2017; Patricola and Wehner 2018). Findings from the present study show that changes in estuarine water quality as a result of Harvey's passage were short-lived.

The short-term impacts to all three systems were reflective of storm surge and flooding that occurred during and following Harvey. In GE, a rapid but ephemeral salinity increase occurred as a result of storm surge, followed by prolonged ( $\sim 1$ month) freshening of the estuary. Valle-Levinson (2020) showed that water levels peaked early on 26 August in GE, then declined rapidly until reaching near pre-storm levels by 29 August. This timeline mirrors the aforementioned salinity trends. Thereafter, the effects of freshwater flooding became more evident. Flooding has been shown to increase external organic matter loadings and strengthen vertical stratification (Paerl et al. 2001) in estuaries, increasing the potential for prolonged bottom water hypoxia (Paerl et al. 2001; Russell et al. 2006; Wong et al. 2010). In this case, salinity stratification at the mid to lower estuary sites in GE likely contributed to the relatively low bottom water D.O. conditions. However, the upper estuary site (site A) had the lowest D.O. but the water column was not stratified. Other studies have shown that following large storm events, the river water that is discharged into the estuary may already be hypoxic and simply displaces oxygenated water in the estuary (Mallin et al. 2002; Tomasko et al. 2006). This likely occurred in the upper estuary in GE, where low $\mathrm{pH}$ and D.O. conditions occurred concomitant with a nearly homogenous fresh water column, indicating that those conditions had a riverine source. Given the magnitude of change in salinity in LC, it is possible that similar phenomena occurred; however, the lower sampling frequency limited our ability to detect this. Several other studies, as well as results presented here from GE, emphasize the importance of high frequency sampling for quantifying the effects of ephemeral extreme climatic events (Paerl et al. 2009; Wetz and Yoskowitz 2013). From a biological standpoint, the low salinity, D.O., and $\mathrm{pH}$ conditions could conceivably have imparted a multi-stressor situation for estuarine organisms. Large salinity swings such as those observed here 
Table 1 Fall season mean $( \pm$ standard deviation), sample size $(n)$, and $p$ value $(p)$ for ANOVA before and after Hurricane Harvey for the Guadalupe (GE), LavacaColorado (LC), and NuecesCorpus (NC) Estuaries. pH was recorded on the bottom; all other variables were collected on the surface

\begin{tabular}{|c|c|c|c|c|c|c|}
\hline System & Variable (units) & $\begin{array}{l}\text { Pre-Harvey fall } \\
\text { mean } \pm \text { SD }\end{array}$ & $n$ & $\begin{array}{l}\text { Post-Harvey fall } \\
\text { mean } \pm \text { SD }\end{array}$ & $n$ & $p$ \\
\hline \multirow[t]{6}{*}{ GE } & Salinity & $21.7 \pm 8.7$ & 16 & $7.8 \pm 7.1$ & 22 & $<0.001$ \\
\hline & $\mathrm{pH}$ & $8.3 \pm 0.3$ & 16 & $8.0 \pm 0.3$ & 20 & 0.015 \\
\hline & Chl $a\left(\mu \mathrm{g} \mathrm{L}^{-1}\right)$ & $15.0 \pm 10.7$ & 16 & $14.3 \pm 9.7$ & 18 & 0.501 \\
\hline & $\mathrm{PO}_{4}\left(\mu \mathrm{mol} \mathrm{L}{ }^{-1}\right)$ & $1.2 \pm 0.6$ & 16 & $5.2 \pm 3.9$ & 19 & $<0.001$ \\
\hline & $\mathrm{NH}_{4}\left(\mu \mathrm{mol} \mathrm{L}{ }^{-1}\right)$ & $0.9 \pm 0.9$ & 16 & $4.1 \pm 4.7$ & 19 & 0.021 \\
\hline & $\mathrm{NO}_{\mathrm{x}}\left(\mu \mathrm{mol} \mathrm{L}{ }^{-1}\right)$ & $0.8 \pm 0.6$ & 16 & $2.4 \pm 2.8$ & 19 & 0.023 \\
\hline \multirow[t]{6}{*}{ LC } & Salinity & $25.1 \pm 6.1$ & 36 & $16 \pm 6.6$ & 15 & $<0.001$ \\
\hline & $\mathrm{pH}$ & $8.2 \pm 0.1$ & 36 & $8.1 \pm 0.1$ & 15 & 0.090 \\
\hline & Chl $a\left(\mu \mathrm{g} \mathrm{L}^{-1}\right)$ & $11.1 \pm 5.9$ & 36 & $16.8 \pm 13.3$ & 15 & 0.016 \\
\hline & $\mathrm{PO}_{4}\left(\mu \mathrm{mol} \mathrm{L}{ }^{-1}\right)$ & $1.2 \pm 0.8$ & 36 & $2.9 \pm 2.3$ & 15 & $<0.001$ \\
\hline & $\mathrm{NH}_{4}\left(\mu \mathrm{mol} \mathrm{L}{ }^{-1}\right)$ & $0.8 \pm 1.1$ & 36 & $1 \pm 0.7$ & 15 & $<0.001$ \\
\hline & $\mathrm{NO}_{\mathrm{x}}(\mu \mathrm{mol} \mathrm{L}-1)$ & $1.1 \pm 1.5$ & 36 & $3.3 \pm 5.1$ & 15 & 0.445 \\
\hline \multirow[t]{6}{*}{$\mathrm{NC}$} & Salinity & $34.5 \pm 4.6$ & 25 & $28.1 \pm 3.7$ & 10 & $<0.001$ \\
\hline & $\mathrm{pH}$ & $8.2 \pm 0.1$ & 25 & $8.1 \pm 0.1$ & 10 & 0.020 \\
\hline & Chl $a\left(\mu \mathrm{g} \mathrm{L}^{-1}\right)$ & $8.7 \pm 4.9$ & 20 & $9.6 \pm 4.1$ & 10 & 0.311 \\
\hline & $\mathrm{PO}_{4}\left(\mu \mathrm{mol} \mathrm{L}{ }^{-1}\right)$ & $0.6 \pm 0.8$ & 20 & $0.8 \pm 1.1$ & 10 & 0.310 \\
\hline & $\mathrm{NH}_{4}\left(\mu \mathrm{mol} \mathrm{L}{ }^{-1}\right)$ & $0.4 \pm 0.3$ & 20 & $1.2 \pm 0.3$ & 10 & $<0.001$ \\
\hline & $\mathrm{NO}_{\mathrm{x}}\left(\mu \mathrm{mol} \mathrm{L}{ }^{-1}\right)$ & $0.4 \pm 0.3$ & 20 & $0.2 \pm<0.1$ & 10 & 0.003 \\
\hline
\end{tabular}

have been shown to have negative impacts on estuarine benthic communities and diversity (Van Diggelen and Montagna 2016). Die-off's of both benthos and nekton have also been observed in response to storm-driven hypoxia/anoxia in the environment (Mallin et al. 1999; Paerl et al. 2001), while laboratory studies have shown that the combination of low D.O. and low $\mathrm{pH}$ negatively affects the health of a broad range of marine life (e.g., Gobler et al. 2014; Gobler and Baumann 2016; Tomasetti et al. 2018). In the case of Harvey, benthic biomass, abundance, and diversity declined and minor shifts
Table 2 Winter season mean $( \pm$ standard deviation), sample size $(n)$, and $p$ value $(p)$ for ANOVA before and after Hurricane Harvey for the Guadalupe (GE), LavacaColorado (LC), and NuecesCorpus (NC) Estuaries. pH was recorded on the bottom; all other variables were collected on the surface

\begin{tabular}{|c|c|c|c|c|c|c|}
\hline System & Variable (units) & $\begin{array}{l}\text { Pre-Harvey winter } \\
\text { mean } \pm \text { SD }\end{array}$ & $n$ & $\begin{array}{l}\text { Post-Harvey winter } \\
\text { mean } \pm \text { SD }\end{array}$ & $n$ & $p$ \\
\hline \multirow[t]{6}{*}{ GE } & Salinity & $19.8 \pm 8.6$ & 20 & $18.4 \pm 5.4$ & 8 & 0.683 \\
\hline & $\mathrm{pH}$ & $8.2 \pm 0.3$ & 20 & $8.4 \pm 0.2$ & 8 & 0.004 \\
\hline & Chl $a\left(\mu \mathrm{g} \mathrm{L}^{-1}\right)$ & $20.3 \pm 18.7$ & 20 & $25.9 \pm 26.1$ & 8 & 0.788 \\
\hline & $\mathrm{PO}_{4}(\mu \mathrm{mol} \mathrm{L}-1)$ & $1.0 \pm 1.4$ & 20 & $0.4 \pm 0.4$ & 8 & 0.886 \\
\hline & $\mathrm{NH}_{4}\left(\mu \mathrm{mol} \mathrm{L}{ }^{-1}\right)$ & $0.6 \pm 0.3$ & 20 & $0.9 \pm 1.0$ & 8 & 0.663 \\
\hline & $\mathrm{NO}_{\mathrm{x}}\left(\mu \mathrm{mol} \mathrm{L}{ }^{-1}\right)$ & $19.3 \pm 32.3$ & 20 & $3.8 \pm 9.1$ & 8 & 0.253 \\
\hline \multirow[t]{6}{*}{ LC } & Salinity & $22.1 \pm 7.9$ & 45 & $21.6 \pm 4.8$ & 15 & 0.385 \\
\hline & $\mathrm{pH}$ & $8.1 \pm 0.2$ & 45 & $8.2 \pm 0.1$ & 15 & 0.191 \\
\hline & Chl $a\left(\mu \mathrm{g} \mathrm{L}^{-1}\right)$ & $6.7 \pm 5.3$ & 45 & $10.4 \pm 14.5$ & 15 & 0.996 \\
\hline & $\mathrm{PO}_{4}\left(\mu \mathrm{mol} \mathrm{L}{ }^{-1}\right)$ & $1.3 \pm 1.3$ & 45 & $1.2 \pm 1.0$ & 15 & 0.289 \\
\hline & $\mathrm{NH}_{4}\left(\mu \mathrm{mol} \mathrm{L}{ }^{-1}\right)$ & $2.4 \pm 4.2$ & 45 & $1.2 \pm 1.4$ & 15 & 0.101 \\
\hline & $\mathrm{NO}_{\mathrm{x}}\left(\mu \mathrm{mol} \mathrm{L} \mathrm{L}^{-1}\right)$ & $13.9 \pm 20.7$ & 45 & $10.2 \pm 23.3$ & 15 & 0.155 \\
\hline \multirow[t]{6}{*}{$\mathrm{NC}$} & Salinity & $32.7 \pm 3.7$ & 25 & $28.4 \pm 2.2$ & 10 & 0.614 \\
\hline & $\mathrm{pH}$ & $8.1 \pm 0.1$ & 25 & $8.2 \pm 0.1$ & 10 & 0.191 \\
\hline & Chl $a\left(\mu \mathrm{g} \mathrm{L}^{-1}\right)$ & $4.2 \pm 4.0$ & 25 & $4.2 \pm 3.0$ & 10 & 0.410 \\
\hline & $\mathrm{PO}_{4}\left(\mu \mathrm{mol} \mathrm{L}{ }^{-1}\right)$ & $0.5 \pm 0.6$ & 25 & $1.1 \pm 1.1$ & 10 & 0.017 \\
\hline & $\mathrm{NH}_{4}\left(\mu \mathrm{mol} \mathrm{L}{ }^{-1}\right)$ & $1.0 \pm 0.8$ & 25 & $1.1 \pm 0.7$ & 10 & 0.829 \\
\hline & $\mathrm{NO}_{\mathrm{x}}\left(\mu \mathrm{mol} \mathrm{L} \mathrm{L}^{-1}\right)$ & $1.4 \pm 1.7$ & 25 & $0.5 \pm 0.6$ & 10 & 0.057 \\
\hline
\end{tabular}


Table 3 Spring season mean $( \pm$ standard deviation), sample size $(n)$, and $p$ value $(p)$ for ANOVA before and after Hurricane Harvey for the Guadalupe (GE), LavacaColorado (LC), and NuecesCorpus (NC) Estuaries. pH was recorded on the bottom; all other variables were collected on the surface

\begin{tabular}{|c|c|c|c|c|c|c|}
\hline System & Variable (units) & $\begin{array}{l}\text { Pre-Harvey spring } \\
\text { mean } \pm \text { SD }\end{array}$ & $n$ & $\begin{array}{l}\text { Post-Harvey spring } \\
\text { mean } \pm \text { SD }\end{array}$ & $n$ & $p$ \\
\hline \multirow[t]{6}{*}{ GE } & Salinity & $16.0 \pm 9.2$ & 24 & $15.2 \pm 5.1$ & 16 & 0.898 \\
\hline & $\mathrm{pH}$ & $8.2 \pm 0.2$ & 24 & $8.0 \pm 0.1$ & 16 & 0.007 \\
\hline & Chl $a\left(\mu \mathrm{g} \mathrm{L}^{-1}\right)$ & $20.7 \pm 15.1$ & 24 & $14.5 \pm 9.7$ & 12 & 0.352 \\
\hline & $\mathrm{PO}_{4}\left(\mu \mathrm{mol} \mathrm{L}{ }^{-1}\right)$ & $1.6 \pm 2.4$ & 24 & $2.0 \pm 1.9$ & 12 & 0.609 \\
\hline & $\mathrm{NH}_{4}\left(\mu \mathrm{mol} \mathrm{L}{ }^{-1}\right)$ & $1.8 \pm 2.3$ & 24 & $10.0 \pm 8.3$ & 12 & 0.001 \\
\hline & $\mathrm{NO}_{\mathrm{x}}\left(\mu \mathrm{mol} \mathrm{L} \mathrm{L}^{-1}\right)$ & $16.8 \pm 35.6$ & 24 & $19.6 \pm 18.2$ & 12 & 0.096 \\
\hline \multirow[t]{6}{*}{$\mathrm{LC}$} & Salinity & $20.2 \pm 9.3$ & 45 & $22.2 \pm 3$ & 9 & 0.934 \\
\hline & $\mathrm{pH}$ & $8.1 \pm 0.2$ & 45 & $8.1 \pm 0.2$ & 9 & 0.017 \\
\hline & Chl $a\left(\mu \mathrm{g} \mathrm{L}^{-1}\right)$ & $9.8 \pm 8.2$ & 45 & $8.8 \pm 6.7$ & 9 & 0.258 \\
\hline & $\mathrm{PO}_{4}\left(\mu \mathrm{mol} \mathrm{L}{ }^{-1}\right)$ & $1.3 \pm 1.8$ & 45 & NA & 0 & NA \\
\hline & $\mathrm{NH}_{4}\left(\mu \mathrm{mol} \mathrm{L}^{-1}\right)$ & $2.6 \pm 3.5$ & 45 & NA & 0 & NA \\
\hline & $\mathrm{NO}_{\mathrm{x}}\left(\mu \mathrm{mol} \mathrm{L}{ }^{-1}\right)$ & $11.6 \pm 19.5$ & 45 & NA & 0 & NA \\
\hline \multirow[t]{6}{*}{$\mathrm{NC}$} & Salinity & $32.0 \pm 2.9$ & 25 & $31.0 \pm 1.5$ & 12 & 0.054 \\
\hline & $\mathrm{pH}$ & $8.0 \pm 0.1$ & 25 & $7.9 \pm 0.4$ & 12 & 0.903 \\
\hline & Chl $a\left(\mu \mathrm{g} \mathrm{L}^{-1}\right)$ & $7.2 \pm 4.4$ & 12 & $7.6 \pm 3.9$ & 24 & 0.749 \\
\hline & $\mathrm{PO}_{4}\left(\mu \mathrm{mol} \mathrm{L}{ }^{-1}\right)$ & $0.4 \pm 0.4$ & 25 & $0.5 \pm 0.4$ & 12 & 0.608 \\
\hline & $\mathrm{NH}_{4}\left(\mu \mathrm{mol} \mathrm{L}^{-1}\right)$ & $1.5 \pm 2.6$ & 25 & $0.5 \pm 0.4$ & 12 & 0.240 \\
\hline & $\mathrm{NO}_{\mathrm{x}}\left(\mu \mathrm{mol} \mathrm{L}{ }^{-1}\right)$ & $1.6 \pm 2.4$ & 25 & $0.5 \pm 0.9$ & 12 & 0.235 \\
\hline
\end{tabular}

in fish community structure were observed, concurrent with reduced catch per unit effort from August to September 2017 in GE (Patrick et al. 2020).

Elevated loadings of inorganic nutrients frequently accompany tropical cyclone passage (Peierls et al. 2003; Paerl et al. 2018). Ammonium increased in all three estuaries while phosphate increased in GE and LC following the storm. Based on the distribution of these nutrients following the storm in GE, it appears that the elevated concentrations were primarily derived from riverine input. We cannot rule out additional contribution from the regeneration of riverine organic matter in the estuary during the hypoxic period however. Hypoxic conditions combined with increased organic carbon availability have been shown to significantly enhance anaerobic nitrate reduction to ammonium in estuaries (Gardner et al. 2006; McCarthy et al. 2008). The onset of anoxia in estuarine bottom waters also induces the release of iron-bound phosphates (Jensen et al. 1995; Sinkko et al. 2013).

Storm-driven nutrient loadings have been shown to be important for stimulating estuarine primary production (Paerl et al. 2001, Paerl 2006). After Harvey, Chl $a$ increased in LC, suggestive of nutrient-stimulated growth. In GE and $\mathrm{NC}$, however, there were no clear impact on $\mathrm{Chl} a$. In the case of GE, a possible reason for this is that the benefits of increased nutrient availability were counterbalanced by detrimental effects of increased flushing and/or to light limitation, as evidenced by a prolonged shallowing of Secchi depth. This has been observed following intense flooding events in other systems (Mallin et al. 2002; Murrell et al. 2007; Paerl et al.
2018), and is consistent with the unimodal distribution between Chl $a$ and inflow that exists in many estuaries (Roelke et al. 2013; Azevedo et al. 2014; Dorado et al. 2015).

The most notable long-term changes ( $>1$ season) after Harvey in GE were elevated ammonium and decreased $\mathrm{pH}$ during the spring of 2018. This is likely due to the breakdown of residual watershed-derived organic matter that was delivered by Harvey but not remineralized in the fall and winter of 2017. Previous studies have shown a strong temperature dependence of bacterial degradation of organic matter, which can often manifest as lags of many months between organic matter inputs and subsequent remineralization in coastal systems (e.g., Cowan and Boynton 1996). In this case, the seasonal decrease in water temperature during winter may have limited remineralization of the organic matter. A plot of ammonium vs. salinity from this timeframe indicates that the increased ammonium occurred primarily at intermediate salinities, pointing to internal regeneration (Fig. S2). Despite the increased ammonium, there was no clear long-term stimulatory effect on Chl $a$ in the system.

The lack of pronounced long-term water quality impacts in any of the three systems sampled here corroborates previous literature showing that estuarine water quality tends to return to baseline conditions within days to a few months after storm passage (Tomasko et al. 2006; Wetz and Yoskowitz 2013), although few studies have examined impacts from a storm of Harvey's magnitude. In the case of Harvey, the return to baseline was somewhat surprising given both the severity of winds associated with it as well as the magnitude of rainfall. 
Furthermore, the affected estuaries are all lagoonal systems with minimal tidal influence. Previous studies have shown that these types of systems are typically susceptible to experiencing negative impacts from high external loadings of organic matter and nutrients (e.g., Bricker et al. 2008; Kennish and Paerl 2010; Wetz et al. 2016). Given that GE and LC in particular have not displayed widespread signs of water quality degradation prior to Harvey (Bugica et al. 2020), it is possible that the impacts of flooding from Harvey were muted because of the seemingly healthy watersheds of these estuaries. This would contrast with examples such as the Neuse River Estuary in North Carolina and Florida Bay, which are experiencing eutrophication due to deleterious changes in the watershed (Paerl et al. 2018; Glibert et al. 2009). Thus, more work may be needed to discern the influence of watershed health on the overall impact of high magnitude storms before broad conclusions can be drawn (Wetz and Yoskowitz 2013). Nonetheless, findings from this study emphasize the resilience of estuarine water quality to external perturbations such as Hurricane Harvey.

Acknowledgments We would like to thank the many people who assisted with this project, including Kalman Bugica, Tiffany Chin, Emily Cira, Kelsey Fisher, Kenneth Hayes, Elani Morgan, Elizabeth Obst, Terry Palmer, and Sarah Tominack. Manuscript contents are solely the responsibility of Walker and do not necessarily represent the official views of the U.S. Department of Commerce, National Oceanic and Atmospheric Administration.

Funding Lily Walker was supported by the National Oceanic and Atmospheric Administration, Office of Education Educational Partnership Program award (NA16SEC4810009). This work was also supported by grants to $\mathrm{PM}, \mathrm{MW}$, and $\mathrm{XH}$ from the National Science Foundation (OCE \#1760006), the National Oceanic and Atmospheric Administration (\#NA15NOS4780185), and partial funding from the Texas Water Development Board.

Open Access This article is licensed under a Creative Commons Attribution 4.0 International License, which permits use, sharing, adaptation, distribution and reproduction in any medium or format, as long as you give appropriate credit to the original author(s) and the source, provide a link to the Creative Commons licence, and indicate if changes were made. The images or other third party material in this article are included in the article's Creative Commons licence, unless indicated otherwise in a credit line to the material. If material is not included in the article's Creative Commons licence and your intended use is not permitted by statutory regulation or exceeds the permitted use, you will need to obtain permission directly from the copyright holder. To view a copy of this licence, visit http://creativecommons.org/licenses/by/4.0/.

\section{References}

Azevedo, I.C., A.A. Bordalo, and P. Duarte. 2014. Influence of freshwater inflow variability on the Douro estuary primary productivity: A modelling study. Ecological Modelling 272: 1-15. https://doi.org/ 10.1016/j.ecolmodel.2013.09.010.

Briceño, H.O., and J.N. Boyer. 2010. Climatic controls on phytoplankton biomass in a sub-tropical estuary, Florida Bay, USA. Estuaries and Coasts 33 (2): 541-553. https://doi.org/10.1007/s12237-009-9189-1.
Bricker, S.B., B. Longstaff, W. Dennison, A. Jones, K. Boicourt, C. Wicks, and J. Woerner. 2008. Effects of nutrient enrichment in the nation's estuaries: A decade of change. Harmful Algae 8 (1): 21-32. https://doi.org/10.1016/j.hal.2008.08.028.

Bugica, K., B. Sterba-Boatwright, and M.S. Wetz. 2020. Water quality trends in Texas estuaries. Marine Pollution Bulletin 152: 110903. https://doi.org/10.1016/j.marpolbul.2020.110903.

Christensen, J.H., K. Krishna Kumar, E. Aldrian, S.-I. An, I.F.A Cavalcanti, M. de Castro, W. Dong, P. Goswami, A. Hall, J.K. Kanyanga, A. Kitoh, J. Kossin, N.-C. Lau, J. Renwick, D.B. Stephenson, S.-P. Xie, and T. Zhou. 2013. Climate phenomena and their relevance for future regional climate change. In: Climate Change 2013: The Physical Science Basis. Contribution of Working Group I to the Fifth Assessment Report of the Intergovernmental Panel on Climate Change. In , ed. T.F. Stocker, D. Qin, G.-K. Plattner, M. Tignor, S.K. Allen, J. Boschung, A. Nauels, Y. Xia, V. Bex, and P.M. Midgley. Cambridge and New York: Cambridge University Press.

Cowan, J.L.W., and W.R. Boynton. 1996. Sediment-water oxygen and nutrient exchanges along the longitudinal axis of Chesapeake Bay: Seasonal patterns, controlling factors and ecological significance. Estuaries 19 (3): 562-580. https://doi.org/10.2307/1352518.

Dorado, S., T. Booe, J. Steichen, A.S. McInnes, R. Windham, A. Shepard, A.E.B. Lucchese, H. Preischel, J.L. Pickney, S.E. Davis, D.L. Roelke, and A. Quigg. 2015. Towards an understanding of the interactions between freshwater inflows and phytoplankton communities in a subtropical estuary in the Gulf of Mexico. PLoS One 10 (7): e0130931. https://doi.org/10.1371/journal.pone.0130931.

Emanuel, K. 2017. Assessing the present and future probability of Hurricane Harvey's rainfall. Proceedings of the National Academy of Sciences 114 (48): 12681-12684. https://doi.org/10.1073/pnas. 1716222114.

Gardner, W.S., M.J. McCarthy, S. An, D. Sobolev, K.S. Sell, and D. Brock. 2006. Nitrogen fixation and dissimilatory nitrate reduction to ammonium (DNRA) support nitrogen dynamics in Texas estuaries. Limnology and Oceanography 51 (1part2): 558-568. https:// doi.org/10.4319/lo.2006.51.1_part_2.0558.

Geyer, N., M. Huettel, and M. Wetz. 2018. Biogeochemistry of a riverdominated estuary influenced by drought and storms. Estuaries and Coasts 41 (7): 2009-2023. https://doi.org/10.1007/s12237-0180411-x.

Glibert, P., C. Heil, D. Rudnick, C. Madden, J. Boyer, and S. Kelley. 2009. Florida Bay: Water quality status and trends, historic and emerging algal bloom problems. Contributions in Marine Science 38: 5-17.

Gobler, C.J., and H. Baumann. 2016. Hypoxia and acidification in ocean ecosystems: Coupled dynamics and effects on marine life. Biology Letters 12 (5): 20150976. https://doi.org/10.1098/rsbl.2015.0976.

Gobler, C.J., E.L. DePasquale, A.W. Griffith, and H. Baumann. 2014. Hypoxia and acidification have additive and synergistic negative effects on the growth, survival, and metamorphosis of early life stage bivalves. Edited by Sam Dupont. PLoS One 9 (1): e83648. https://doi.org/10.1371/journal.pone.0083648.

Hagy, J.D., J.C. Lehrter, and M.C. Murrell. 2006. Effects of Hurricane Ivan on water quality in Pensacola Bay, Florida. Estuaries and Coasts 29 (6): 919-925. https://doi.org/10.1007/BF02798651.

Jensen, H.S., P.B. Mortensen, F.Ø. Andersen, E. Rasmussen, and A. Jensen. 1995. Phosphorus cycling in a coastal marine sediment, Aarhus Bay, Denmark. Limnology and Oceanography 40 (5): 908-917. https://doi.org/10.4319/lo.1995.40.5.0908.

Kennish, M.J., and H.W. Paerl. 2010. Coastal lagoons: Critical habitats of environmental change, 1 st ed. Boca Ratorn: CRC Marine Science. CRC Press.

Knefelkamp, B., K. Carstens, and K.H. Wiltshire. 2007. Comparison of different filter types on chlorophyll-a retention and nutrient 
measurements. Journal of Experimental Marine Biology and Ecology 345 (1): 61-70. https://doi.org/10.1016/j.jembe.2007.01. 008 .

Knutson, T.R., J.J. Sirutis, M. Zhao, R.E. Tuleya, M. Bender, G.A. Vecchi, G. Villarini, and D. Chavas. 2015. Global projections of intense tropical cyclone activity for the late twenty-first century from dynamical downscaling of CMIP5/RCP4.5 scenarios. Journal of Climate 28 (18): 7203-7224. https://doi.org/10.1175/JCLI-D-150129.1.

Lee, T.N., N. Melo, N. Smith, E.M. Johns, C.R. Kelble, R.H. Smith, and P.B. Ortner. 2016. Circulation and water renewal of Florida Bay, USA. Bulletin of Marine Science 92 (2): 153-180. https://doi.org/ 10.5343/bms.2015.1019.

Mallin, M.A., M.H. Posey, G.C. Shank, M.R. McIver, S.H. Ensign, and T.D. Alphin. 1999. Hurricane effects on water quality and benthos in the Cape Fear watershed: Natural and anthropogenic impacts. Ecological Applications 9 (1): 350-362. https://doi.org/10.1890/ 1051-0761(1999)009[0350:HEOWQA]2.0.CO;2.

Mallin, M.A., M.H. Posey, M.R. McIver, D.C. Parsons, S.H. Ensign, and T.D. Alphin. 2002. Impacts and recovery from multiple hurricanes in a piedmont-coastal plain river system: Human development of floodplains greatly compounds the impacts of hurricanes on water quality and aquatic life. BioScience 52 (11): 999-1010. https://doi. org/10.1641/0006-3568(2002)052[0999:IARFMH]2.0.CO;2.

McCarthy, M.J., K.S. McNeal, J.W. Morse, and W.S. Gardner. 2008. Bottom-water hypoxia effects on sediment-water interface nitrogen transformations in a seasonally hypoxic, shallow bay (Corpus Christi Bay, TX, USA). Estuaries and Coasts 31 (3): 521-531. https://doi.org/10.1007/s12237-008-9041-z.

Montagna, P.A., T.A. Palmer, and J. Beseres Pollack. 2013. Hydrological changes and estuarine dynamics. Vol. 8. SpringerBriefs in Environmental Science. New York: Springer New York.

Montagna, P.A., X. Hu, T.A. Palmer, and M. Wetz. 2018. Effect of hydrological variability on the biogeochemistry of estuaries across a regional climatic gradient. Limnology and Oceanography 63 (6): 2465-2478. https://doi.org/10.1002/lno.10953.

Murrell, M.C., J.D. Hagy, E.M. Lores, and R.M. Greene. 2007. Phytoplankton production and nutrient distributions in a subtropical estuary: Importance of freshwater flow. Estuaries and Coasts 30 (3): 390-402. https://doi.org/10.1007/BF02819386.

Paerl, H.W. 2006. Assessing and managing nutrient-enhanced eutrophication in estuarine and coastal waters: Interactive effects of human and climatic perturbations. Ecological Engineering 26 (1): 40-54. https://doi.org/10.1016/j.ecoleng.2005.09.006.

Paerl, H.W., J.L. Pinckney, J.M. Fear, and B.L. Peierls. 1998. Ecosystem responses to internal and watershed organic matter loading: Consequences for hypoxia in the Eutrophying Neuse River Estuary, North Carolina, USA. Marine Ecology Progress Series 166: 17-25. https://doi.org/10.3354/meps 166017

Paerl, H.W., J.D. Bales, L.W. Ausley, C.P. Buzzelli, L.B. Crowder, L.A. Eby, J.M. Fear, M. Go, B.L. Peierls, T.L. Richardson, and J.S. Ramus. 2001. Ecosystem impacts of three sequential hurricanes (Dennis, Floyd, and Irene) on the United States' largest lagoonal estuary, Pamlico Sound, NC. Proceedings of the National Academy of Sciences 98 (10): 5655-5660. https://doi.org/10.1073/ pnas.101097398.

Paerl, H.W., K.L. Rossignol, R. Guajardo, N.S. Hall, A.R. Joyner, and B.L. Peierls. 2009. FerryMon: Ferry-based monitoring and assessment of human and climatically driven environmental change in the Albemarle-Pamlico Sound system. Environmental Science \& Technology 43 (20): 7609-7613.

Paerl, H.W., J.R. Crosswell, B. Van Dam, N.S. Hall, K.L. Rossignol, C.L. Osburn, A.G. Hounshell, R.S. Sloup, and L.W. Harding. 2018. Two decades of tropical cyclone impacts on North Carolina's estuarine carbon, nutrient and phytoplankton dynamics: Implications for biogeochemical cycling and water quality in a stormier world. Biogeochemistry 141 (3): 307-332. https://doi.org/ 10.1007/s10533-018-0438-x.

Patrick, C.J., L. Yeager, A.R. Armitage, F. Carvallo, V.M. Congdon, K.H. Dunton, M. Fisher, A.K. Hardison, J.D. Hogan, J. Hosen, X. Hu, B. Kiel Reese, S. Kinard, J.S. Kominoski, X. Lin, Z. Liu, P.A. Montagna, S.C. Pennings, L. Walker, C.A. Weaver, and M. Wetz. 2020. A system level analysis of coastal ecosystem responses to hurricane impacts. Estuaries and Coasts 43 (5): 943-959. https:// doi.org/10.1007/s12237-019-00690-3.

Patricola, C.M., and M.F. Wehner. 2018. Anthropogenic influences on major tropical cyclone events. Nature 563 (7731): 339-346. https:// doi.org/10.1038/s41586-018-0673-2.

Peierls, B.L., R.R. Christian, and H.W. Paerl. 2003. Water quality and phytoplankton as indicators of hurricane impacts on a large estuarine ecosystem. Estuaries 26 (5): 1329-1343.

Roelke, D.L., H.P. Li, N.J. Hayden, C.J. Miller, S.E. Davis, A. Quigg, and Y. Buyukates. 2013. Co-occurring and opposing freshwater inflow effects on phytoplankton biomass, productivity and community composition of Galveston Bay, USA. Marine Ecology Progress Series 477: 61-76. https://doi.org/10.3354/meps10182.

Russell, M.J., P.A. Montagna, and R.D. Kalke. 2006. The effect of freshwater inflow on net ecosystem metabolism in Lavaca Bay, Texas. Estuarine, Coastal and Shelf Science 68 (1-2): 231-244. https://doi. org/10.1016/j.ecss.2006.02.005.

Sinkko, H., K. Lukkari, L.M. Sihvonen, K. Sivonen, M. Leivuori, M. Rantanen, L. Paulin, and C. Lyra. 2013. Bacteria contribute to sediment nutrient release and reflect progressed eutrophication-driven hypoxia in an organic-rich continental sea. PLoS One 8 (6): e67061. https://doi.org/10.1371/journal.pone.0067061.

Tomasetti, S.J., B.K. Morrell, L.R. Merlo, and C.J. Gobler. 2018. Individual and combined effects of low dissolved oxygen and low $\mathrm{pH}$ on survival of early stage larval blue crabs, Callinectes sapidus. Edited by Thiyagarajan Vengatesen. PLoS One 13 (12): e0208629. https://doi.org/10.1371/journal.pone.0208629.

Tomasko, D.A., C. Anastasiou, and C. Kovach. 2006. Dissolved oxygen dynamics in Charlotte Harbor and its contributing watershed, in response to hurricanes Charley, Frances, and Jeanne-Impacts and recovery. Estuaries and Coasts 29 (6): 932-938. https://doi.org/10. 1007/BF02798653.

Valiela, I., P. Peckol, C.A. D’Avanzo, J. Kremer, D. Hersh, K. Foreman, K. Lajtha, et al. 1998. Ecological effects of major storms on coastal watersheds and coastal waters: Hurricane Bob on Cape Cod. Journal of Coastal Research 14: 218-238 JSTOR.

Valle-Levinson, A., M. Olabarrieta, and L. Heilman. 2020. Compound flooding in Houston-Galveston Bay during Hurricane Harvey. Science of The Total Environment 747: 141272. https://doi.org/10. 1016/j.scitotenv.2020.141272.

Van Diggelen, A.D., and P.A. Montagna. 2016. Is salinity variability a benthic disturbance in estuaries? Estuaries and Coasts 39 (4): 967 980. https://doi.org/10.1007/s12237-015-0058-9.

Wetz, M.S., and D.W. Yoskowitz. 2013. An 'extreme' future for estuaries? Effects of extreme climatic events on estuarine water quality and ecology. Marine Pollution Bulletin 69 (1-2): 7-18. https://doi. org/10.1016/j.marpolbul.2013.01.020.

Wetz, M.S., K.C. Hayes, K.V.B. Fisher, L. Price, and B. SterbaBoatwright. 2016. Water quality dynamics in an urbanizing subtropical estuary (Oso Bay, Texas). Marine Pollution Bulletin 104 (1-2): 44-53. https://doi.org/10.1016/j.marpolbul.2016.02.013.

Wong, V.N.L., S.G. Johnston, R.T. Bush, L.A. Sullivan, C. Clay, E.D. Burton, and P.G. Slavich. 2010. Spatial and temporal changes in estuarine water quality during a post-flood hypoxic event. Estuarine, Coastal and Shelf Science 87 (1): 73-82. https://doi. org/10.1016/j.ecss.2009.12.015.

Zetler, B.D., and D.V. Hansen. 1970. Tides in the Gulf of Mexico -A review and proposed program. Bulletin of Marine Science 20: 57 69. 